\title{
Proceeding
}

Supplementary Issue: Summer Conferences of Sports Science. First International Conference in Iraq on Sport for Peace, 4 April 2019. Baghdad Science Institute, Baghdad, Iraq.

\section{The knowledge management, product innovation, and process innovation as antecedents of sports manufacturing firms of Thailand}

\author{
SAKAPAS SAENGCHAI ${ }^{1}$, AKSORN SAWASDEE 2 , KITTISAK JERMSITTIPARSERT ${ }^{3,4}$ \\ ${ }^{1}$ Faculty of Humanities and Social Science, Suan Sunandha Rajabhat University, Bangkok, Thailand \\ ${ }^{2}$ Faculty of Humanities and Social Sciences, Phranakhon Rajabhat University, Bangkok, Thailand \\ ${ }^{3}$ Department for Management of Science and Technology Development, Ton Duc Thang University, Ho Chi \\ Minh City, Vietnam \\ ${ }^{4}$ Faculty of Social Sciences and Humanities, Ton Duc Thang University, Ho Chi Minh City, Vietnam
}

\begin{abstract}
The main purpose of the currents study is to explore the nexus knowledge management, product innovation, and process innovation as antecedents of sports manufacturing firms of Thailand In order to analyse the relation of operational performance and knowledge management processes, a theoretical framework has been developed through innovation of product and processes in the manufacturing companies of Jordan. Based on this research, it was revealed that there is a significant and positive influence of knowledge management on both innovation types (innovation of product and processes). When innovation is considered as a competitive strategy by the manufacturing companies, they are required to start knowledge management program for supporting innovation. It has been indicated by the research findings that the innovation of process influences the operational efficiency in a positive way. However, innovation of product does not create an influence. There is need for the companies to focus on the innovation process, which aim to improve their operational performance. The study has used survey-based methodology and SEM-PLS is employed to analyse the data. This contributes to the improvements in quality, reduction of cost, and upgrading of response. Innovation of product can result in various benefits along with operational performance of the organization. Keywords: Knowledge management; Innovation; Sports; Thailand.

Cite this article as:

Saengchai, S., Sawasdee, A., \& Jermsittiparsert, K. (2019). The knowledge management, product innovation, and process innovation as antecedents of sports manufacturing firms of Thailand. Journal of Human Sport and Exercise, 14(5proc), S2217-S2231. doi:https://doi.org/10.14198/ihse.2019.14.Proc5.40

Corresponding author. Department for Management of Science and Technology Development, Ton Duc Thang University, Ho Chi Minh City, Vietnam.

E-mail: kittisak.jermsittiparsert@tdtu.edu.vn

Supplementary Issue: Summer Conferences of Sports Science. First International Conference in Iraq on Sport for Peace, 4 April 2019. Baghdad Science Institute, Baghdad, Iraq.

JOURNAL OF HUMAN SPORT \& EXERCISE ISSN 1988-5202

(C) Faculty of Education. University of Alicante

doi:10.14198/jhse.2019.14.Proc5.40
\end{abstract}




\section{INTRODUCTION}

Intense business competition, technological advancements, and dynamic markets characterize the business environment in which manufacturing organizations operate. Some of the prominent factors include globalization, latest revolutions in the production and information technology, agreements of free trade, and reduced life cycle of products along with variations in consumer needs. Resultantly, organizations in the manufacturing sector are being pressurized to use resources, which increases their operational efficiency and result in competitive advantage.

Innovation and knowledge management are the significant optional strategies that can improve the ability of organization to fulfil the needs of customers and comply with the changing technologies. In this way, the organizations become able to maintain their competitive advantage in the rapidly changing environment (Costa \& Monteiro, 2016; Dahiyat, 2015). Alternatively, the relation between performance and KM has been analysed in literature. The focus is on the determination of performance in terms of competitiveness, effectiveness, and market performance and balanced scorecard (Mahdavi Mazdeh \& Hesamamiri, 2014; Soto-Acosta, Popa, \& Palacios-Marqués, 2016). There is limited number of studies on analysing the influence of KM on operational performance. The efficiency and effectiveness of the manufacturing organizations is predicted through operational performance. Operational performance reflects the proficient management of managing and using resources for innovation in product management. Moreover, there exists a gap in research about the direct and indirect influence created by KM on performance (Hamid, 2015). The relation of performance and innovation is not clear and existing researches provide incomplete and contradictory results. There is need for analysing relations about various types of innovation and firm's performance (Ganter \& Hecker, 2014). Researchers are working on finding the influence of different innovation types on the companies' operational performance. Moreover, rare studies have worked on analysing the relation between innovation, KM, and operational performance (Wang et al, 2016). When new knowledge is incorporated with the current information to improve the competencies and capabilities, innovation is resulted. Considering this aspect, the processes related to sourcing and creation of new knowledge and its integration in the existing knowledge of organization are included in $\mathrm{KM}$. The innovation process of an organization is significantly influenced by KM. The important role of KM in supporting innovation has been emphasized in the theoretical literature. However, there is no empirical study depicting clear results (Crespi et al, 2016). There is need for empirical investigation for the role of $\mathrm{KM}$ on innovation of process and product. Further, the existing studies have focused on the developed economies. Greater challenges are experienced by the manufacturing companies in emerging economies to deal with the global competition. This study contributes to the existing literature by analysing the hypothesized relations in the emerging country (Jordan). A twofold contribution has been made by this study for analysing the direct and indirect influences created by KM on the organization's operational performance. The study has incorporated the innovation of product and innovation as mediators. Moreover, the study has determined the contributions of innovation in process and product to operation performance. A consensus exists between researchers that there is positive relation of innovation with the performance. However, the existing studies have not worked on the relation of innovations in process and product with the operational performance (Wang et al., 2016).

\section{LITERATURE REVIEW}

The innovation of product and innovation of process have been used as mediators in this research to test the relation of OP and KM (Maroofi, 2015; Sutduean et al, 2019; Jermsittiparsert et al , 2019). It has been hypothesized that both the innovation types are influenced by KM in a positive way. Moreover, it has been assumed in the research model that innovation of product and innovation of process create a positive 
influence on OP. The proposed model in this research is based on RBV (resource-based view) (Kull, Mena et al, 2016). The internal resources implications are underlined in the RBV theory to reach the firm's superior performance. It is assumed by the theory that resources are valuable, rate, imitable and non-substitutable. Moreover, the resources support in the achievement of competitive advantage (Bromiley \& Rau, 2016; Costa \& Monteiro, 2016; Dahiyat, 2015). It has been argued that manufacturing companies become able to innovation through KM capability, which improves the operational performance of an organization. The crucial antecedent of innovation is KM (Costa \& Monteiro, 2016; Dahiyat, 2015). Moreover, the innovation is promoted through KM by generation of new ideas and their exploitation in the intellectual capital of an organization. New knowledge is developed and transformed through acquisition of external knowledge (Inkinen et al, 2015; Jermsittiparsert \& Srisawat, 2019). In this way, new knowledge can be developed. Similarly, the new transformed knowledge can be utilized in an efficient way to reduce the uncertainty and improve the level of knowledge. Opportunities are provided through new acquired knowledge for the creation of environment, which is innovation. This leads to improved innovation (Ramadan et al , 2017). The process of transfer of skills, experiences, and knowledge exchange is supported through sharing of knowledge that results in the creation of new thinking models and routines (Karamitri et al , 2017). Moreover, the effort and time is decreased through sharing of knowledge, which is required by the employees for acquisition of information. The organizational resources are transferred to support the process of innovation. Learning is improved and new knowledge is accessed through exchange and sharing of knowledge that is the foundation for diffusion of creative ideas (Inkinen et al., 2015). The benefits of knowledge application occur at two levels. The first is linked with the use of existing knowledge for problem solving. The second is related to making knowledge active in the formation of related organizational values. The ability of an organization to apply knowledge is increased efficiently to manage different knowledge resources, reduction of errors, and transformation of gathered knowledge to get benefits in terms of innovation in organization (Villar et al , 2014). Consequently, the innovation of product and processes is increased through knowledge application in organizations. Practically, serious issues are experienced by organizations without the knowledge application. The collective knowledge cannot be used in an effective manner for improve the innovation performance to the expected level (Villar et al., 2014). The potential advantages of application of KM have increased its interest for the organizations. The potential advantages include increase in employee's creativity, innovative ideas and increasing the innovation of processes and products (Maroofi, 2015). The most evident result of KM is innovation. Moreover, new knowledge can be created through KM. However, it is crucial for getting benefits related to innovation. The influence of KM processes on the innovation of product and process has been investigated by several studies empirically. It was found by (Waribugo et al, 2016) that a significant and positive influence is created by KM processes on innovativeness in Turkey. It was found that innovation of product is influence by KM in a significant way. In Luxembourg, the innovation of product is influenced by the KM and innovation is process is linked with the organizational process. A sample based on companies working in technological sector was used by (Donate \& de Pablo ,2015) from Spain. The study found that the influence of knowledge-oriented leadership with innovation of product is mediated by KM. A sample based on 221 companies including China, Russia, China, and Finland was used by (Cohen \& Olsen ,2015) and it was found that innovation is positively influenced by KM. It was found that dynamic performance and innovation is influenced positively through organizational practices related to knowledge and learning in Danish organizations. Empirical evidence was provided from the manufacturing companies of Malaysia about the influence of KM on the innovation of technology. It was claimed that practices including application of knowledge, sharing of knowledge, and storage of knowledge affect the innovation of product and processes in a positive way. The influence of KM created on innovation of service was demonstrated by (Koloniari, et al, 2015) in academic libraries. Therefore, $\mathrm{H} 1$ has been hypothesized as below:

$\mathrm{H} 1$ : KNM has significant impact on PRDIN

H2: KNM has significant impact on PRICIN 
The significance of KM refers to the capability of offering innovative ways for achieving the knowledge sharing (implicit and explicit). A valuable source to improve the organizational performance and achievement of competitive advantage is provided through sharing of intellectual assets (Zebal et al, 2019). Competitiveness can be maintained by organizations when they create, gather, transfer, and use knowledge for problem solving by utilizing the opportunities available. Such organizations are eager to enhance their abilities in response to the environmental changes. Moreover, the overall performance of organizations is improved through development of innovative ideas and reduction in redundancy. Moreover, acquisition of knowledge and acquisition between the groups and individuals in an organization influence the process of decisionmaking. Consequently, organizations need to involve employees in the processes of KM by use of expertise and knowledge to support effectiveness and value creation for the organization. It was argued by (Tseng \& Lee ,2014) that the ability of KM program to affect the performance of organization determines its success. The relation between performance and KM has been investigated by several studies. It was demonstrated by (Kasemsap ,2017) that the organizational effectiveness is positively influenced by KM capability. It was found that there is a positive and significant relation between competitiveness and KM. It was concluded by (Hussinki et al, 2017) that the overall performance of the organization is positively linked with KM such as human resource and market performance. It was found by (Ha et al, 2016) that the financial performance is directly linked with the KM capability. It was found that the overall performance of organizations is linked with the knowledge. Using a sample of 245 organizations based in North American region, it was found by (Mahdavi Mazdeh \& Hesamamiri ,2014) that the measures of performance a significantly influenced by KM. These measures include internal, financial and processes. A sample of 68 organizations in Korea, which adopted KM were used. The researchers found that there is a significant relation between performance, processes, and capabilities of KM. It was argued by (Soto-Acosta et al, 2016) that there is direct relation of $\mathrm{KM}$ processes and market performance but an indirect relation with the financial performance.

H3: KNM has significant impact on OPRPER

In order to improve the value of organization and its performance, innovation is highly important (Jermsittiparsert et al, 2019). The organizations, which are innovation, show higher productivity and economic growth as compared with those, which are not innovative Excellence is achieved by organizations in terms of quality, cost, flexibility, and delivery, when organizations focus on innovation in products and services. It has been shown by several studies that the relation between performance and innovation is strong and positive. It was found by (Kafetzopoulos \& Psomas ,2015) that there is positive relation of performance and productivity with the level of innovation. It was concluded that innovation of process and product has a positive association with the production performance because of the business and operational models used (Maroofi, 2015). In the similar way, when organizations are involved in innovation, they are successful in improving their financial and operational performance. It was indicated (Blind et al , 2017) that operational benefits are provided by innovation through use of novel technology in order to improve the performance of product. It was further revealed that the performance is improved by innovation through gains in productivity and efficiency. By using innovation methods of production, the response time is reduced, quality is improved, and costs are reduced. It was asserted that innovation of process enhances the operations in internal production, which results in reduction of cost and increase in operational efficiency. The ability to respond to the external changes is increased by the product innovation through formation of new capacities. Development of new capabilities results in greater operational performance (Wang et al., 2016). Therefore, the following hypothesis has been proposed.

H4: PRDTIN has significant impact on OPRPER

H5: PRICEIN has significant impact on OPRPER 
Different arguments support this positive influence. Moreover, organizations become able to innovate in processes and products. The literature has widely discussed the influence of innovation types on the operational efficiency of an organization. It has been argued by this study that when organizations work on innovation of processes and product, KM has a greater influence on the operational performance. In addition to the direct influence created on operational performance by KM, two innovation types create indirect influences. The real exploitation of resources results in this indirect influence (Kasemsap, 2016b). Organizations are provided with the ability to efficiently design and innovate the processes through knowledge capability, which improves the delivery, flexibility, and quality, along with reduction in cost. Operational performance is influenced by process innovation, as there are improvements in the efficiency of production and processes (Prajogo \& Oke, 2016). Further, when innovation based knowledge is exclusive, the competitive advantage achieved by organization cannot be imitated from the perspective of RBV (Bromiley \& Rau, 2016; Kull et al., 2016). It was indicated by (Zakery \& Afrazeh ,2017) that companies become able to innovate and improve their performance and operational efficiency through KM. Manufacturers are forced to improve their agility and customer response rate in this dynamic business environment. However, effective KM is required by those competencies, which support the organizational resource transformation into competencies and capabilities (Maroofi, 2015). Creativity and innovation in processes and products is increased by KM. In turn, this increases the operational performance of an organization. Operational efficiency improves through increase in innovation of process by reduction of costs, improvement of processes, efficiency, and productivity (Bhatti et al, 2016). The quality of product is improved through improvements in product innovation. The improvements in technology result in development of new products, which have greater value and performance. Moreover, the operational performance is influenced by KM through innovation of process and products. This enables the companies to focus on activities that add value based on the type of innovation. The role of innovation in the relation of performance and KM has been addressed by several studies. (Kasemsap,2016a) explored the influence of innovation of product and process on the relation of KM and performance among the SMEs of Spain. It was found by the study that capability of knowledge combination is influenced by innovation in process and product. It was also found that both innovation types create a mediating influence on the relation of organizational performance and capability of knowledge combination. It was found by (Ahmad \& Al-Shbiel ,2019) that organizational performance is positively influenced by KM. the researchers worked on a sample based on the leading companies of Serbia. The results empirically reflected that the innovation of process and administration influence KM positively. Moreover, a significant influenced has been found by the innovation of process and administration on the relation of organizational performance and KM. Using a sample based on the public sector organizations of Iran, found that the organizational innovation and performance is positively influenced by KM processes. It was also found that organizational innovation act as a mediator in the relation of performance and KM. The influence of KM on organizational flexibility and innovation was analysed in the organizations of Ugandan parastatal. The researchers found that innovation is significantly influenced by KM and flexibility is affected insignificantly. It was also found that innovation fully mediates the relation of flexibility and innovation. By using a sample of 310 organizations in Spain, (Hamid ,2015) found that the internal and corporate financial performance is directly influenced by personalization and codification (two KM strategies). The literature does not have investigation on the role of innovation in process and product as mediators on operational performance and KM. these arguments have been used to develop the following research hypothesis.

H6: PRDTIN mediates the relationship KNM and OPRPER

$\mathrm{H} 7$ : PRICEIN mediates the relationship KNM and OPRPER 


\section{MEASUREMENT AND METHODS}

The literature has been used to adopt the measurement items for the constructs. The KM processes have been measured by the items proposed by (Rodger et al, 2019). The innovation of product and service was measured by the items proposed. The operational efficiency was measured through the items given. Measurement scales, which were adopted, were in line with the definitions of variables in the study. The systematic and explicit management of important knowledge and related process of gathering, sharing and using it for achieving the set objectives is referred as KM (Asiaei \& Bontis, 2019). The products provided by the organization to benefit the customers are referred as product innovation. The improvements and changes in the processes to enhance the effectiveness, efficiency, and productivity of the activities are referred as process innovation. The performance of internal organizational activities such as quality, cost, flexibility, and delivery is referred as operational performance (Dabhilkar, et al, 2016). In order to avoid any confusion, the scales of measurements were changed into Thai langue. Five professors reviewed these scales, made changes, and required. It was asked by the respondents to evaluate their level of disagreement and agreement with the structured statements. For this, a five-point Likert scale was used in which 1 reflected strongly disagree and 5 shows strongly agree. Data analysis was based on inferential and descriptive statistics. The use of SPSS 22.0 was made for descriptive analysis. It helps in understanding the demographic variables and profile of respondents. In order to get comprehension of the concept, the variability and central tendency of the data was shown in descriptive statistics. Moreover, PLS-SEM was used in Smart PLS 3.0 to perform the inferential analysis. For obtaining sufficient rate of response, several phone calls were made to the selected firms accompanied with the follow up visits. Consequently, nine public universities were targeted for the survey and the questionnaires received were 360 . The response rate was about $60 \%$. Almost nine questionnaires had missing values and excluded from the analysis. The response rate decreased to $58.50 \%$. As per the suggestion of (Padlee et al, 2016), the response rate can be considered sufficient. The researcher recommended that the response rate of 30 percent could be regarded as sufficient. SEM is recently being used greatly because of its ability to analyse the multivariate data in social and behavioural sciences. For this reason, its use has increased in the education studies. The relation between the latent and observed variables can be analysed simultaneously through use of SEM groups.

\section{RESULTS}

The use of SEM is beneficial when the intentions, attitudes, perceptions, characteristics, and attributes linked with educational research cannot be observed directly. The factor analysis and linear regression analysis are involved in SEM. By using the framework of SEM, two approaches including PLS-SEM and CB-SEM can be used for analysis. The most common method of analysis is CB-SEM. This is applied frequently in AMOS, LISREL, and MPLUS. Different procedures of estimation are applied in every type of SEM with different objectives and by using different assumptions of distribution. The approach was firstly developed (Hair et al , 2014). The purpose of the approach is to maximize the variable of dependent variable through use of OLS method of estimation. Specifically, this study has adopted PLS method because of various reasons. The PLS method is effective, when the research model has several manifest and unobserved variables. It is an effective method for the complicated models. Further, PLS path model approach can be applied in the estimate of models with reflective and formative measurements (Henseler et al, 2015). The error of measurement can be explained by PLS and this can result is accurate estimates of mediation and moderation effects (Hair et al , 2016). It was suggested by Hair, Hult, Ringle, and Thiele (2017) that complex models can be estimated by PLS path modelling, which involve the role of mediating and moderating factors along with hierarchical constructs. Moreover, the results found by PLS-SEM are valid and expressive. However, the 
results obtained from other studies are not conclusive and need separate analysis (Hair et al., 2017). Based on these advantages, the use of PLS-SEM has been made in this research rather than CB-SEM.

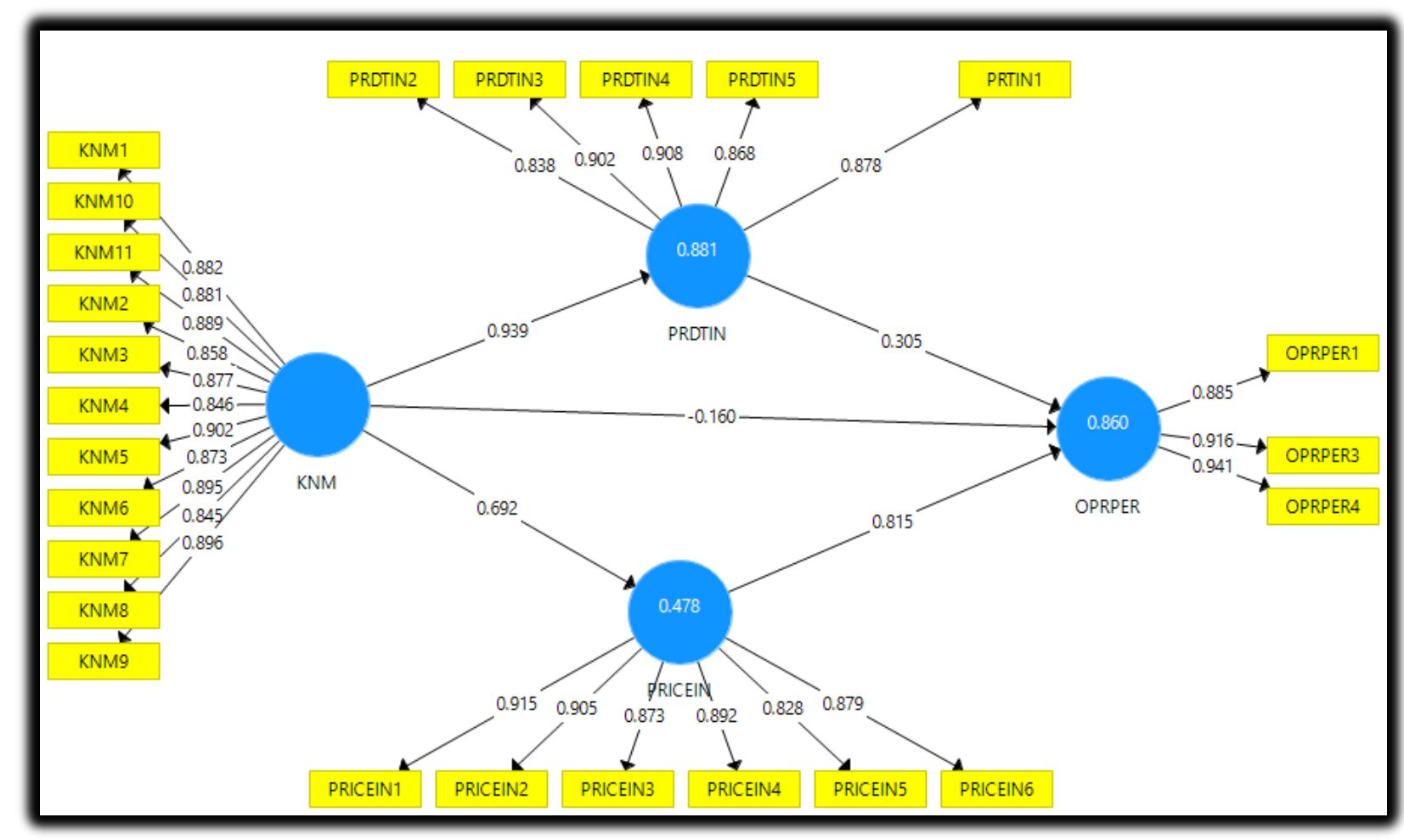

Figure 1. Measurement Model.

The relevance of loadings of indicators has been determined in the measurement model for the specific constructs. It is ensured through reliability that the measurement instrument is consistent for with what it was expected to measure. The ability of the research instrument to determine the variable that it needs to measure is referred as validity (Janadari et al, 2016). The relation between the observed and unobserved constructs is established in the outer model determination. In outer model determination, estimates of content and the validity (discriminant and convergent) of the constructs are measured (Hair et al., 2014).The PLS-SEM method was used to evaluate the individual's outer loadings for the item reliability of variables. The items with the loadings in the range of 0.4-0.7 are retained in the model (Hair et al., 2014). When the value of loadings is greater or equal to 0.70, this refers to the retention of item loadings (Hair et al., 2014; Henseler et al., 2015). The value of item loadings lower than 0.3 is regarded as weak and 0.55 as moderate. When the value is in range of 0.60-0.8, it is considered suitable or strong when it lies between 0.8-1 (Hair et al., 2014). Further, the value of item loadings should be higher than 0.3 for mutual association of variables.

The level with which the two measures assumed to be associated with each other come out to be related in the analysis is referred as convergent validity. The measures used for the determination of convergent validity involve composite reliability, factor loadings and AVE (Hair et al., 2010). In this way, the values of item loadings are determined. The acceptable values involve item loadings with value equal or greater than 0.5 (Hair et al., 2014; Tzempelikos \& Gounaris, 2017). The results reflect that all the item loadings are greater than 0.50 as shown in Table 4.5. Further, the level with which the relevant construct is indicated by the items is referred as composite reliability (Hair et al., 2014). The value of CR that can be accepted should be equal 
or higher than 0.7 (Hair et al., 2014; Tzempelikos \& Gounaris, 2017). It is shown in Table 4.5 that the values of $\mathrm{CR}$ for all the variables lie in the range of 0.872 and 0.968 that is higher than the standard value. The extent of variance between the indicators of unobserved variables is regarded as AVE (Hair et al., 2017). The standard value of AVE is equal or greater than 0.5 (Hair et al., 2014; Tzempelikos \& Gounaris, 2017). It is shown in Table 2 that the values of AVE for all the variables lie in the range 0.512 to 0.834 , which refers to the convergent validity. Table 2 shows the values of $C R$ for work commitment i.e. dependent variable.

Tale 1. Outer Loadings.

\begin{tabular}{|l|l|l|l|l|}
\hline & KNM & OPRPER & PRDTIN & PRICEIN \\
\hline KNM1 & 0.882 & & & \\
\hline KNM10 & 0.881 & & & \\
\hline KNM11 & 0.889 & & & \\
\hline KNM2 & 0.858 & & & \\
\hline KNM3 & 0.877 & & & \\
\hline KNM4 & 0.846 & & & \\
\hline KNM5 & 0.902 & & & \\
\hline KNM6 & 0.873 & & & \\
\hline KNM7 & 0.895 & & & \\
\hline KNM8 & 0.845 & & & \\
\hline KNM9 & 0.896 & & & \\
\hline OPRPER1 & & 0.885 & & \\
\hline OPRPER3 & & 0.916 & & \\
\hline OPRPER4 & & 0.941 & & \\
\hline PRDTIN2 & & & 0.838 & \\
\hline PRDTIN3 & & & 0.902 & \\
\hline PRDTIN4 & & & 0.908 & \\
\hline PRDTIN5 & & & 0.868 & \\
\hline PRICEIN1 & & & & 0.915 \\
\hline PRICEIN2 & & & & 0.873 \\
\hline PRICEIN3 & & & & 0.892 \\
\hline PRICEIN4 & & & & \\
\hline PRICEIN5 & & & & \\
\hline PRICEIN6 & & & & \\
\hline PRTIN1 & & & & \\
\hline
\end{tabular}

Table 2. Reliability.

\begin{tabular}{|l|l|l|l|l|}
\hline & Cronbach's Alpha & rho_A & CR & (AVE) \\
\hline KNM & 0.970 & 0.971 & 0.973 & 0.769 \\
\hline OPRPER & 0.901 & 0.904 & 0.938 & 0.835 \\
\hline PRDTIN & 0.926 & 0.927 & 0.944 & 0.773 \\
\hline PRICEIN & 0.943 & 0.944 & 0.955 & 0.778 \\
\hline
\end{tabular}

It is determined in the discriminant validity whether a specific measure related with other measures or not. The outer model's construct validity is ensured. It was suggested by Ahmadian and Abdolmaleki (2018) that the square root of AVE should be examined with the correlation of the unobserved variables. It is suggested 
that the value of AVE should be higher than the value of correlation between the unobserved variables. The inner model has been evaluated after the outer model.

Tale 3. Discriminant Validity.

\begin{tabular}{|l|l|l|l|l|}
\hline & KNM & OPRPER & PRDTIN & PRICEIN \\
\hline KNM & 0.877 & & & \\
\hline OPRPER & 0.790 & 0.894 & & \\
\hline PRDTIN & 0.739 & 0.726 & 0.879 & \\
\hline PRICEIN & 0.692 & 0.818 & 0.701 & 0.882 \\
\hline
\end{tabular}

The hypotheses have been tested by calculating the t-values. The Smart PLS 3.0 has been used for bootstrapping procedure based on resample of 500 to ensure the path coefficient significance (Ahmadian \& Abdolmaleki, 2018). It was suggested by the researcher that sufficient estimates of standard error could be resulted by using $200-1000$ bootstrap samples. The significance of path coefficient can be determined based on the method of bootstrapping used in software of Smart PLS.

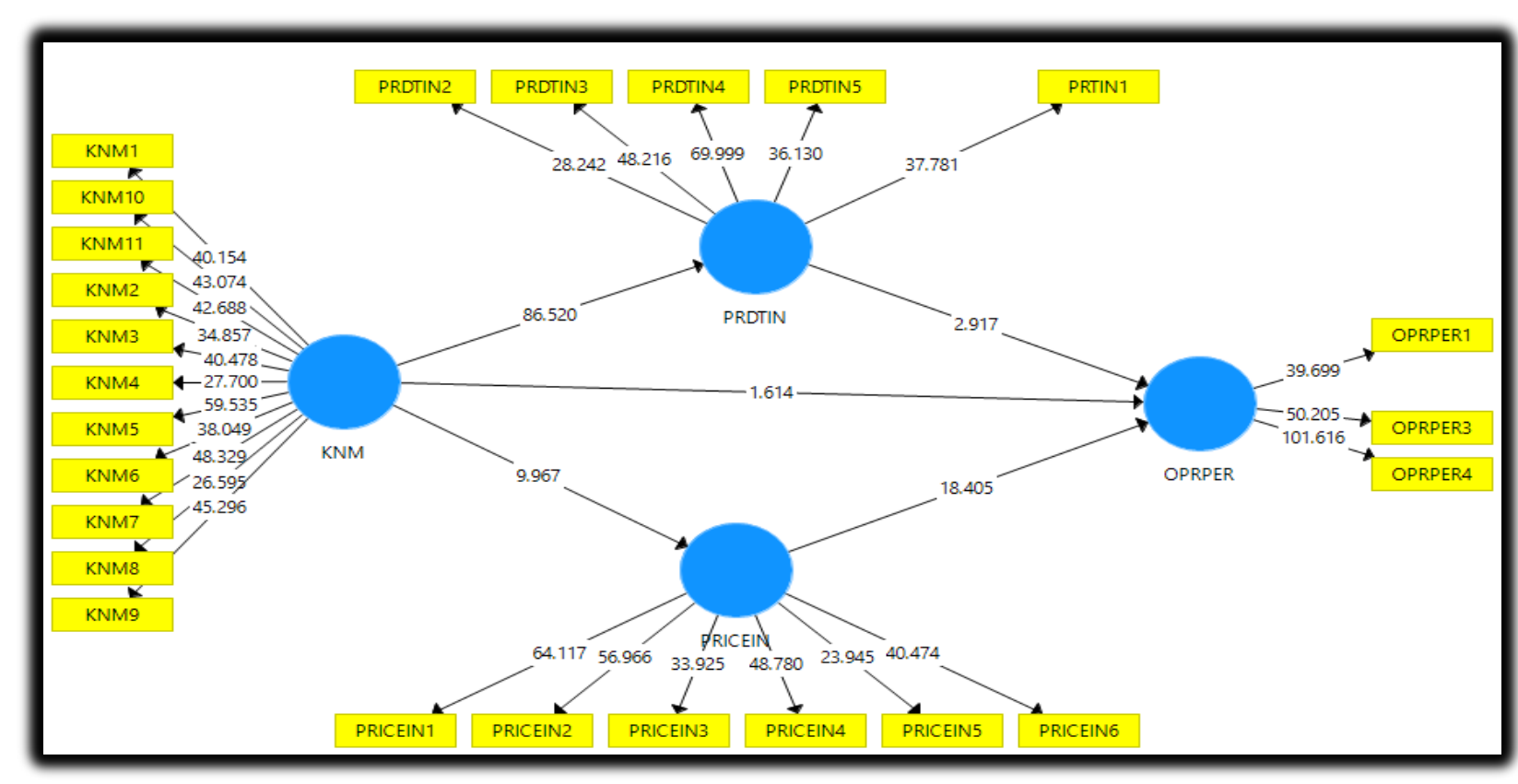

Figure 2. Structural Model.

Table 4. Direct Relationship.

\begin{tabular}{|l|l|l|l|l|l|}
\hline & $(\mathbf{O})$ & $(\mathbf{M})$ & (STDEV) & $($ (O/STDEV $\mid)$ & P Values \\
\hline KNM -> OPRPER & 0.160 & 0.158 & 0.099 & 1.614 & $\mathbf{0 . 0 5 3}$ \\
\hline KNM -> PRDTIN & 0.939 & 0.939 & 0.011 & 86.520 & $\mathbf{0 . 0 0 0}$ \\
\hline KNM -> PRICEIN & 0.692 & 0.693 & 0.069 & 9.967 & $\mathbf{0 . 0 0 0}$ \\
\hline PRDTIN -> OPRPER & 0.305 & 0.310 & 0.104 & 2.917 & $\mathbf{0 . 0 0 2}$ \\
\hline PRICEIN -> OPRPER & 0.815 & 0.809 & 0.044 & 18.405 & $\mathbf{0 . 0 0 0}$ \\
\hline
\end{tabular}


Table 5. Mediation.

\begin{tabular}{|l|l|l|l|l|l|}
\hline & $(\mathbf{O})$ & $(\mathrm{M})$ & STDEV) & |O/STDEV|) & P Values \\
\hline KNM -> PRDTIN -> OPRPER & 0.286 & 0.291 & 0.098 & 2.912 & $\mathbf{0 . 0 0 2}$ \\
\hline KNM -> PRICEIN -> OPRPER & 0.564 & 0.559 & 0.045 & 12.500 & $\mathbf{0 . 0 0 0}$ \\
\hline
\end{tabular}

An important condition in the determination of structural model is the assessment of R2 (coefficient of determination) (Hair et al., 2017). R2 indicates the strength of model. It explains the variation in the dependent variable caused by the explanatory variables. It is indicated by literature that the minimum value of $R 2$, which can be accepted is 0.1 (Hair et al., 2014). The value of R2 is weak when it is far below 0.5 and it is stronger when it is near 1. The coefficient of determination in this study has been shown in Table 6 for the criterion variable, i.e. work commitment.

Table 6. R-square.

\begin{tabular}{|l|l|}
\hline & R Square \\
\hline OPRPER & 0.860 \\
\hline PRDTIN & 0.881 \\
\hline PRICEIN & 0.478 \\
\hline
\end{tabular}

As per the suggestion of (Hair et al, 2014), the model's predictive relevance has been measured to determine the quality of model. The predictive relevance can be evaluated through use of measure of cross-validated redundancy (Q2). When the value of Q2 is greater than 0, it shows predictive relevance for the dependent variable (Hair et al., 2014).

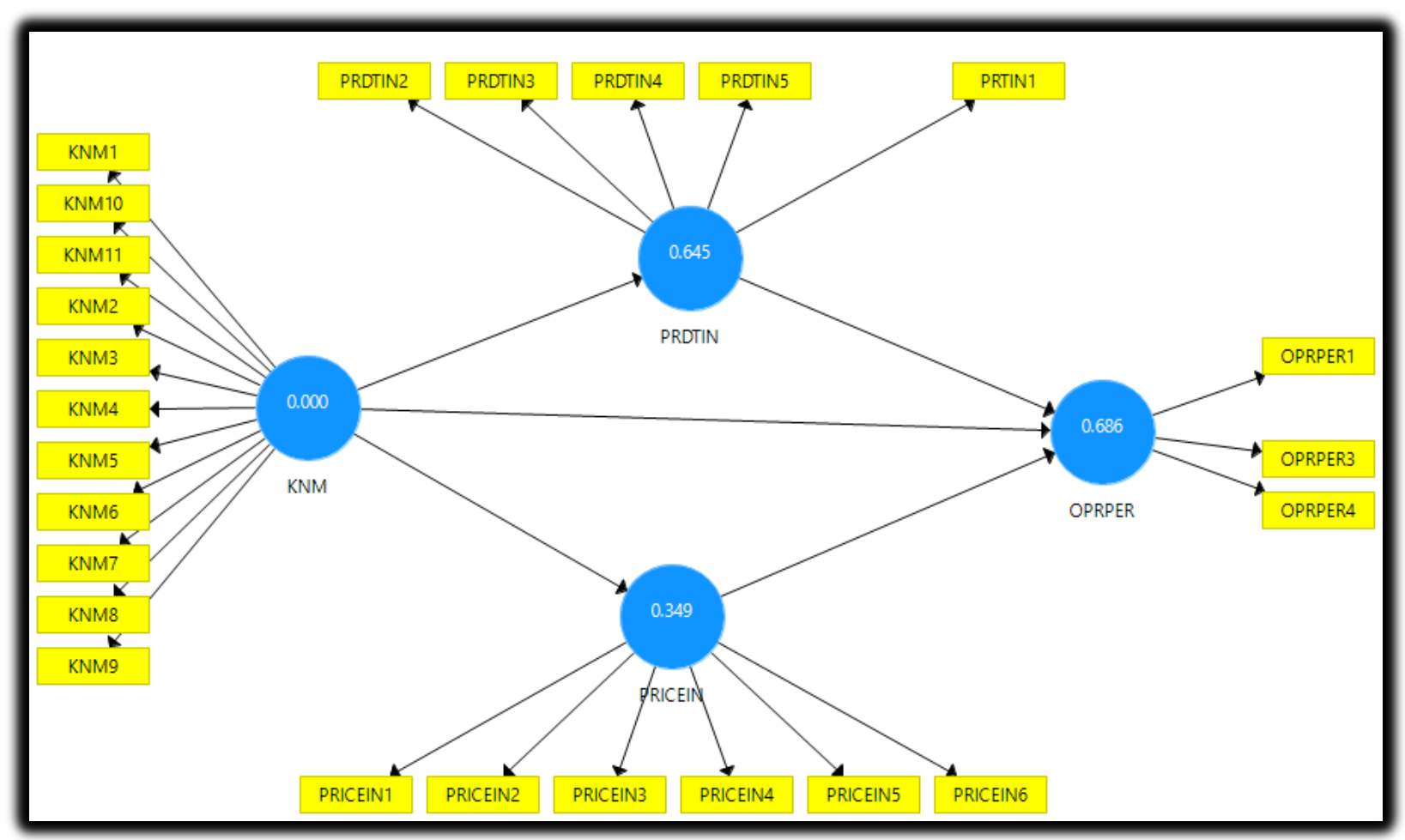

Figure 3. Q-square. 
When it is zero, the model has no predictive relevance. The process of blindfolding is used in Smart PLS software for the determination of predictive relevance. Because of missing values, few cases were excluded in the process of blindfolding (Ahmadian \& Abdolmaleki, 2018; Hair et al., 2014).

Table 7. Blindfolding's.

\begin{tabular}{|l|l|l|l|}
\hline & SSO & SSE & $\mathbf{Q}^{2}$ (=1-SSE/SSO) \\
\hline KNM & $2,387.000$ & $2,387.000$ & \\
\hline OPRPER & 651.000 & 204.509 & 0.686 \\
\hline PRDTIN & $1,085.000$ & 385.708 & 0.645 \\
\hline PRICEIN & $1,302.000$ & 847.069 & 0.349 \\
\hline
\end{tabular}

\section{CONCLUSION}

In order to analyse the relation of operational performance and KM processes, a theoretical framework has been developed through innovation of product and processes in the manufacturing companies of Jordan (Wang et al., 2016). Based on this research, it was revealed that there is a significant and positive influence of KM on both innovation types (innovation of product and processes). When innovation is considered as a competitive strategy by the manufacturing companies, they are required to start KM program for supporting innovation. It has been indicated by the research findings that the innovation of process influences the operational efficiency in a positive way. However, innovation of product does not create an influence. There is need for the companies to focus on the innovation process, which aim to improve their operational performance (Wang et al., 2016). This contributes to the improvements in quality, reduction of cost, and upgrading of response. Innovation of product can result in various benefits along with operational performance of the organization. It is indicated by the results that KM has a direct influence on the operational performance. Manufacturing companies can accumulate valuable knowledge through an effective KM program. The valuable knowledge can be sourced from both external and internal sources. Use of internal and external knowledge in an organized way can add value to the operational performance along with achievement of competitive advantage for the firm (Costa \& Monteiro, 2016; Dahiyat, 2015). The results reveal that the innovation of process has a positive mediating influence on the relation of operational performance and KM. innovation of process enables the achievement of potential benefits of KM created on operational performance. Some benefits for the performance are achieved through imitation, which add to the sustainable competitive advantage. Such capabilities are hard to be imitated by the competitors. The results are consistent with the perspective of RBV (Kull et al., 2016). The role of internal competences and capabilities.

\section{MANAGERIAL IMPLICATIONS}

Important managerial implications have been found by this study. The manufacturing companies must focus on the KM processes for innovation of process and products. Innovations can be done through acquisition of knowledge from external resources i.e. suppliers and customers. Moreover, new knowledge can be generated by the internal ability from the current knowledge. This requires a systematic approach for gathering ideas and suggestions of employees along with flexibility for application and sharing of knowledge. The innovation capability is enhanced in the processes and products. In order to improve the operational performance, KM processes have a significant role (Wang et al., 2016). The organizational capability for reducing cost, improving quality, decreasing time of delivery and lead-time is improved through KM. Higher innovation cannot be made just through knowledge. It requires the KM processes and company's members to share, transfer, and utilize knowledge. Additional emphasize should be given by the managers to the role 
of innovation types in improve the operational performance. The achievement of organizational objectives is improved through suitable type of innovation. Process innovation should be adopted by the managers for achieving operational efficiency as compared with the product innovation. Companies become able to decrease cost in the production processes through process innovation (Prajogo \& Oke, 2016). Moreover, the quality of products can be increased by eliminating the activities, which does not add value. The product innovation has been linked with the other dimensions of performance including market share, growth of sales, and financial performance. However, the product innovation has found to be not linked with operational performance in this research study. Efforts and resources are sacrificed by companies, which focus on innovation of product for improving the operational performance without the achievement of expected outcomes. Manufacturing companies are supported by influence of innovation types on the operational performance in prioritizing their expenditures. In this way, the right technologies, strategies, and processes are selected by the companies. A direct influence is created by KM processes on the operational performance of companies. There is need for the managers to focus on such performance, which can be influenced through improving the capability of process innovation (Prajogo \& Oke, 2016). KM processes should be directed to improve the innovation of process, which enhances the operational performance in this competitive and dynamic business environment. Operational efficiency cannot be optimized by the managers without considering the relation of KM and OP. Moreover, it is crucial for the managers to do process innovation, which cannot be imitated by the competitors. In this way, competitive advantage can be achieved and sustained because of unique knowledge in innovation of process (Mrożewski \& Kratzer, 2017).

\section{REFERENCES}

Ahmad, M. A., \& Al-Shbiel, S. O. (2019). The Effect of Accounting Information System on Organizational Performance in Jordanian Industrial SMEs: The Mediating Role of Knowledge Management. International Journal of Business and Social Science, 10(3). https://doi.org/10.30845/ijbss.v10n3p9

Ahmadian, S., \& Abdolmaleki, S. (2018). Network typology and international opportunity recognition: moderating role of entrepreneurial orientation. Journal of Global Entrepreneurship Research, 8(1), 17. https://doi.org/10.1186/s40497-018-0104-8

Asiaei, K., \& Bontis, N. (2019). Translating knowledge management into performance: the role of performance measurement systems. Management Research Review. https://doi.org/10.1108/mrr10-2018-0395

Bhatti, W. A., Larimo, J., \& Carrasco, I. (2016). Strategy's effect on knowledge sharing in host country networks. Journal of Business Research, 69(11), 4769-4774. https://doi.org/10.1016/j.jbusres.2016.04.028

Blind, K., Petersen, S. S., \& Riillo, C. A. (2017). The impact of standards and regulation on innovation in uncertain markets. Research Policy, 46(1), 249-264. https://doi.org/10.1016/j.respol.2016.11.003

Bromiley, P., \& Rau, D. (2016). Operations management and the resource based view: Another view. Journal of Operations Management, 41, 95-106. https://doi.org/10.1016/i.jom.2015.11.003

Cohen, J. F., \& Olsen, K. (2015). Knowledge management capabilities and firm performance: A test of universalistic, contingency and complementarity perspectives. Expert Systems with Applications, 42(3), 1178-1188. https://doi.org/10.1016/j.eswa.2014.09.002

Costa, V., \& Monteiro, S. (2016). Knowledge processes, absorptive capacity and innovation: A mediation analysis. Knowledge and Process Management, 23(3), 207-218.

https://doi.org/10.1002/kpm.1507

Crespi, G., Tacsir, E., \& Vargas, F. (2016). Innovation dynamics and productivity: Evidence for Latin America Firm Innovation and Productivity in Latin America and the Caribbean (pp. 37-71): Palgrave Macmillan, New York. https://doi.org/10.1057/978-1-349-58151-1_2 
Dabhilkar, M., Bengtsson, L., \& Lakemond, N. (2016). Sustainable supply management as a purchasing capability: A power and dependence perspective. International Journal of Operations \& Production Management, 36(1), 2-22. https://doi.org/10.1108/ijopm-12-2014-0609

Dahiyat, S. E. (2015). An integrated model of knowledge acquisition and innovation: examining the mediation effects of knowledge integration and knowledge application. International Journal of Learning and change, 8(2), 101-135. https://doi.org/10.1504/ijlc.2015.074064

Donate, M. J., \& de Pablo, J. D. S. (2015). The role of knowledge-oriented leadership in knowledge management practices and innovation. Journal of Business Research, 68(2), 360-370. https://doi.org/10.1016/i.jbusres.2014.06.022

Ganter, A., \& Hecker, A. (2014). Configurational paths to organizational innovation: qualitative comparative analyses of antecedents and contingencies. Journal of Business Research, 67(6), 1285-1292. https://doi.org/10.1016/i.jbusres.2013.03.004

Ha, S.-T., Lo, M.-C., \& Wang, Y.-C. (2016). Relationship between knowledge management and organizational performance: a test on SMEs in Malaysia. Procedia-Social and Behavioral Sciences, 224, 184-189. https://doi.org/10.1016/i.sbspro.2016.05.438

Hair, Hult, G. T. M., Ringle, C., \& Sarstedt, M. (2016). A primer on partial least squares structural equation modeling (PLS-SEM): Sage publications. https://doi.org/10.3926/oss.37

Hair, Hult, G. T. M., Ringle, C. M., \& Thiele, K. O. (2017). Mirror, mirror on the wall: a comparative evaluation of composite-based structural equation modeling methods. Journal of the Academy of Marketing Science, 45(5), 616-632. https://doi.org/10.1007/s11747-017-0517-x

Hair, Sarstedt, M., \& Hopkins, L., Kuppelwieser, Volker. (2014). Partial least squares structural equation modeling (PLS-SEM) An emerging tool in business research. European Business Review, 26(2), 106-121. https://doi.org/10.1108/ebr-10-2013-0128

Hamid, S. A. (2015). Investigating the knowledge sharing activities among postgraduates students using social media tools. Universiti Utara Malaysia.

Henseler, J., Ringle, C. M., \& Sarstedt, M. (2015). A new criterion for assessing discriminant validity in variance-based structural equation modeling. Journal of the Academy of Marketing Science, 43(1), 115-135. https://doi.org/10.1007/s11747-014-0403-8

Hussinki, H., Kianto, A., \& Vanhala, M., Ritala, Paavo. (2017). Assessing the universality of knowledge management practices. Journal of Knowledge Management, 21(6), 1596-1621. https://doi.org/10.1108/jkm-09-2016-0394

Inkinen, H. T., Kianto, A., \& Vanhala, M. (2015). Knowledge management practices and innovation performance in Finland. Baltic Journal of Management, 10(4), 432-455. https://doi.org/10.1108/bim10-2014-0178

Janadari, M., Sri Ramalu, S., \& Wei, C. (2016). Evaluation of measurment and structural model of the reflective model constructs in PLS-SEM.

Jermsittiparsert, K. \& Srisawat, S. (2019). Complexities in a Flexible Supply Chain and the Role of Knowledge Transfer. Humanities and Social Sciences Reviews, 7(2), 531-538. https://doi.org/10.18510/hssr.2019.7263

Jermsittiparsert, K., Sutduean, J., \& Sriyakul, T. (2019). Effect of Service Innovation and Market Intelligence on Supply Chain Performance in Indonesian Fishing Industry. Industrial Engineering \& Management Systems, 18(3), 408-417. https://doi.org/10.7232/iems.2019.18.3.407

Jermsittiparsert, K., Sutduean, J., \& Sutduean, C. (2019). The Mediating Role of Innovation Performance between the Relationship of Green Supply Chain Management Skills and Environmental Performance. International Journal of Supply Chain Management, 8(3), 107-119. https://doi.org/10.7232/iems.2019.18.3.407 
Kafetzopoulos, D., \& Psomas, E. (2015). The impact of innovation capability on the performance of manufacturing companies: The Greek case. Journal of Manufacturing Technology Management, 26(1), 104-130. https://doi.org/10.1108/imtm-12-2012-0117

Karamitri, I., Talias, M. A., \& Bellali, T. (2017). Knowledge management practices in healthcare settings: a systematic review. The International journal of health planning and management, 32(1), 4-18. https://doi.org/10.1002/hpm.2303

Kasemsap, K. (2016a). Creating product innovation strategies through knowledge management in global business Civil and Environmental Engineering: Concepts, Methodologies, Tools, and Applications (pp. 1-26): IGI Global. https://doi.org/10.4018/978-1-4666-9619-8.ch001

Kasemsap, K. (2016b). Developing a framework of human resource management, organizational learning, knowledge management capability, and organizational performance Project Management: Concepts, Methodologies, Tools, and Applications (pp. 371-402): IGI Global. https://doi.org/10.4018/978-1-5225-0196-1.ch018

Kasemsap, K. (2017). Strategic innovation management: An integrative framework and causal model of knowledge management, strategic orientation, organizational innovation, and organizational performance Organizational Culture and Behavior: Concepts, Methodologies, Tools, and Applications (pp. 86-101): IGI Global. https://doi.org/10.4018/978-1-5225-1913-3.ch005

Koloniari, M., Vraimaki, E., \& Fassoulis, K. (2015). A study of KM critical success factors in Greek academic libraries. International Journal on Integrated Information Management, 2(2), 1-12. https://doi.org/10.15556/iiiim.02.02.001

Kull, A. J., Mena, J. A., \& Korschun, D. (2016). A resource-based view of stakeholder marketing. Journal of Business Research, 69(12), 5553-5560. https://doi.org/10.1016/j.jbusres.2016.03.063

Mahdavi Mazdeh, M., \& Hesamamiri, R. (2014). Knowledge management reliability and its impact on organizational performance: an empirical study. Program, 48(2), 102-126. https://doi.org/10.1108/prog-01-2013-0001

Maroofi, F. (2015). Strategic Knowledge Management, Innovation, and Performance Encyclopedia of Information Science and Technology, Third Edition (pp. 4709-4719): IGI Global. https://doi.org/10.4018/978-1-4666-5888-2.ch462

Mrożewski, M., \& Kratzer, J. (2017). Entrepreneurship and country-level innovation: Investigating the role of entrepreneurial opportunities. The Journal of Technology Transfer, 42(5), 1125-1142. https://doi.org/10.1007/s10961-016-9479-2

Padlee, S. F., Nur, S., \& Zulkiffli, A. (2016). Examining the Moderating Effects of Students' Characteristics on the Relationship between Perceived Quality and Satisfaction with University Services: The Evidence from two Public Universities in Terengganu. International Review of Management and Marketing, 6(3), 460-466.

Prajogo, D. I., \& Oke, A. (2016). Human capital, service innovation advantage, and business performance: The moderating roles of dynamic and competitive environments. International Journal of Operations \& Production Management, 36(9), 974-994. https://doi.org/10.1108/ijopm-11-2014$\underline{0537}$

Ramadan, B. M., Dahiyat, S. E., \& Bontis, N., Al-Dalahmeh, Mahmoud Ali. (2017). Intellectual capital, knowledge management and social capital within the ICT sector in Jordan. Journal of Intellectual Capital, 18(2), 437-462. https://doi.org/10.1108/iic-06-2016-0067

Rodger, J. A., Chaudhary, P., \& Bhatt, G. (2019). Refining information systems competencies: the role of big data analytics resilience in organisational learning. International Journal of Business Intelligence and Systems Engineering, 1(3), 226-250. https://doi.org/10.1504/ijbise.2019.10020306 
Soto-Acosta, P., Popa, S., \& Palacios-Marqués, D. (2016). E-business, organizational innovation and firm performance in manufacturing SMEs: an empirical study in Spain. Technological and Economic Development of Economy, 22(6), 885-904. https://doi.org/10.3846/20294913.2015.1074126

Sutduean, J., Harakan, A., \& Jermsittiparsert, K. (2019). Exploring the Relationship between Supply Chain Integration, Product Innovation, Supply Chain Performance and Firm Performance: Does Supply Chain Information Strategy Matter?. International Journal of Innovation, Creativity and Change, 5(2), 175-192. https://doi.org/10.18510/hssr.2019.73102

Tseng, S.-M., \& Lee, P.-S. (2014). The effect of knowledge management capability and dynamic capability on organizational performance. Journal of Enterprise Information Management, 27(2), 158179. https://doi.org/10.1108/jeim-05-2012-0025

Tzempelikos, N., \& Gounaris, S. (2017). A conceptual and empirical examination of key account management orientation and its implications-the role of trust The Customer is NOT Always Right? Marketing Orientationsin a Dynamic Business World (pp. 673-681): Springer. https://doi.org/10.1007/978-3-319-50008-9_185

Villar, C., Alegre, J., \& Pla-Barber, J. (2014). Exploring the role of knowledge management practices on exports: A dynamic capabilities view. International Business Review, 23(1), 38-44. https://doi.org/10.1016/j.ibusrev.2013.08.008

Wang, Z., Wang, N., \& Cao, J., Ye, Xinfeng. (2016). The impact of intellectual capital-knowledge management strategy fit on firm performance. Management Decision, 54(8), 1861-1885. https://doi.org/10.1108/md-06-2015-0231

Waribugo, S., Ofoegbu, W., \& Akpan, E. (2016). The Impact of Knowledge Management on Product Innovation of Manufacturing Firms in Nigeria.

Zakery, A., \& Afrazeh, A. (2017). Analysing intellectual capital management and growth based on dynamic modelling. Knowledge management research \& practice, 15(1), 101-113. https://doi.org/10.1057/s41275-016-0040-8

Zebal, M., Ferdous, A., \& Chambers, C. (2019). An integrated model of marketing knowledge-a tacit knowledge perspective. Journal of Research in Marketing and Entrepreneurship. https://doi.org/10.1108/jrme-03-2018-0018

\section{(@) $\odot \Theta \Theta$}

This work is licensed under a Attribution-NonCommercial-NoDerivatives 4.0 International (CC BY-NC-ND 4.0). 